Łukasz Jan Berezowski

Uniwersytet Łódzki

\title{
TRANSLATING LATIN LEGALESE: BETWEEN DYNAMIC EQUIVALENCE AND FORMAL CORRESPONDENCE. A COMPARATIVE STUDY CASE OF LATIN LEGAL TERMS AND MAXIMS IN ENGLISH, ITALIAN AND POLISH LANGUAGE
}

\begin{abstract}
The aim of this article is to outline some theoretical problems related to the incompatibility of formal use of several Latin expressions present in English, Italian and Polish lexis as well as to propose solutions for facing practical cases of translation troubles based on the experience of the author gathered as academic, court translator and lay judge. The corpus shall be divided into the categories of lexemes utilized respectively in the European Union law such as (1) legal source texts, (2) procedural documents, (3) jurisprudence. The quoted examples aim to meet the initial assumption about the incompatibility as well as partial or non-equivalence of Latin terms among the examined study cases in selected representatives of Germanic, Romance and Slavonic languages.

Keywords: dynamic equivalence, European Union Law, formal correspondence, Latin legal maxims, semantic incompatibility of legal terms

Tradurre il legalese latino: tra l'equivalenza dinamica e la corrispondenza formale. Il caso di studio comparativo dei termini e dei brocardi latini in inglese, italiano e polacco Riassunto

L'obiettivo del presente articolo è quello di delineare alcuni problemi teorici inerenti all'incompatibilità dell'uso formale di alcune espressioni latine presenti nel lessico della lingua inglese, italiana e polacca a confronto nonché di proporre soluzioni per affrontare casi pratici delle difficoltà di traduzione basate sull'esperienza dell'autore accumulate nel corso degli anni in qualità di docente universitario, traduttore/interprete del tribunale e giudice popolare. Il corpus è articolato in categorie di lemmi utilizzati rispettivamente nel diritto dell'Unione Europea che consiste di (1) atti normativi, (2) documentazione processuale, (3) testi di giurisprudenza. Gli esempi citati mirano a soddisfare l'ipotesi iniziale sull'incompatibilità nonché sull'equivalenza parziale o non-equivalenza dei termini latini attraverso i casi esaminati nei rappresentanti dei gruppi di lingue germaniche, romanze e slave.

Parole chiave: brocardi latini, corrispondenza formale, diritto dell'Unione Europea, equivalenza dinamica, incompatibilità semantica dei termini legali
\end{abstract}




\section{Introduction: definition of "legal language", "language of the law" and "legalese"}

Legal language is a subgenre of standard language used prevalently in legal writing and court pleadings. It has been referred to as a "sublanguage" or a "subcode" since as its diaphasical variation differs from ordinary language in terms of lexis, word sequence, morphology and semantics, as well as in several other linguistic and non-linguistic aspects (register, style, tone, etc.). The way legal language is processed shall be determined by the use of specialized terminology and distinct linguistic model rules. Thus, as Jill J. Ramsfield claims, legal language is apprehended "as a kind of second language, a specialized use of vocabulary, phrases, and syntax that helps us to communicate more easily with each other" (Ramsfield, 2005: 145).

There are many different genres of legal language including, first of all, academic legal writing as the one published in law journals and magazines, secondly juridical legal writing as in any procedural documents (including court rulings and orders), and finally legislative legal writing as in acts, regulations, international conventions and treaties. All of them represent a very hermetic and exclusive type of communication addressed to a limited target group. Analogous classification might be found in Italian linguistics: suffice to mention a triple taxonomy provided in the work by Bice Mortara Garavelli (2001: 25), where the three pillars have been named as normative (including codes and laws), interpretative (comments, opinions) and applicative (procedural documents). Similar observations were made long before in the field of Polish legal theory by Bronisław Wróblewski (1948: 56, 136-140) where language of the law [PL: jezzyk prawny] was defined as the language used primarily by the legislature, whilst legal language [PL: jezzyk prawniczy] is the metalanguage of the law applied by legal practitioners and professional representatives coping with the law. In later works of Polish scholars such as Maciej Zieliński to be mentioned (1999: 5074), Wróblewski's dichotomous categorization was developed by subdividing language of the law into (1) language of legal provisions (1a) and language of legal norms (1b), as into pure legal language ( $2 a)$ through language of legal practice of jurisprudence (2a) and non-jurisprudence (2b), as well as of language of legal doctrine (2c), popular science ( $2 \mathrm{~d}$ ) and education (2e), as observed and translated into English by Dariusz Koźbiał (2020: 42).

Alongside the given definitions of legal language and language of the law, the term "legalese" is also occurable which, on the other hand, represents a pejorative construct associated with a conservative style of legal writing that is part of this specialized discourse of lawyers: a type of communication that "lay readers cannot readily comprehend", as Oates and Enquist defined it (2009: 127). Therefore, legalese describes a kind of legal writing that is pompous, indirect and 
includes loads of unnecessary technical expressions or phrases. From historical perspective, legalese represents a language that lawyers would use in drafting a contract or a procedural writ but would not in a usual conversation, especially when talking to their clients. For that reason, the traditional style of legal writing has been regarded as unfriendly to readers but still omnipresent and frequently adopted in legal circles.

\section{Latinisms and the law: current research status}

A relevant characteristic of communication between lawyers is the use of Latinisms. It seems clear enough that most legal practitioners utilize Latin terms and maxims a lot in their daily praxis. One of the reason for this is the ancient Roman law system that has had a strong impact on the national legislatures of most European countries and overseas, which has simultaneously left many contemporary languages with certain discrepancies of their legal vocabulary in the semantic aspect. De cuius, pro tempore, subpoena - these and other expressions are present in the awareness of professional language of attorneys, judges and law academics across the world due to common Latin heritage. The problem that those and many others bring about for translators is that their semantic distribution shifts in each European language (even in the legal systems following directly ius civile tradition like Italy or Poland but also inside the language of EU law). As a consequence, their frequency of usage varies depending on the particular context where some maxims deriving from Latin are permitted, while in others - partially or not at all.

The overlap of legal Latinisms between national corpora in question arises from different level of integration of these terms locally: ascending from the lowest where complex phrases occur as separate sentences and remain mostly unchanged through instances in which components of maxims, especially nominal ones, are expressed in Latin, to the highest degree of integration which covers Latin words and phrases found in non-legal writings, too. Probably the first to have observed the described tendency was Dennis Kurzon (1987: 233-240) who paid attention to the occurrence of Latin words and phrases in English legal texts, with particular reference to possible impediments faced by lawyers and their readers. In Italy Bice Mortara Garavelli established that among 1,010 Latin words registered in Grande Dizionario Italiano dell'Uso di Mauro only 163 typically belong to legal language which represents 16,13\% overall (Mortara Garavelli, 2002: 424). In the Polish field of legal linguistics much effort have been done within the PL Eurolect project headed by Łucja Biel and her team of scholars from the Institute of Applied Linguistics (University of Warsaw) where, among others, the research into 4498 Latinisms was carried out, out of which 25 most recurrent types have been identified. The results of the analysis 
have been exhaustively described in the latterly released The Language of EU and Polish Judges: Investigating Textual Fit Through Corpus Methods by Dariusz Koźbiał (Peter Lang Publishing, 2020).

\section{Methodology}

Following the theoretical background mentioned in the first two sections, I would like to proceed with the proper analysis of several Latin expressions existing, coexisting, but simultaneously inexistent in English, Italian and Polish language. My reasoning is based on the comparative approach to parallel corpus texts accumulated in open domain website EUR-LEX (http://eur-lex.europa.eu), an authorized source of European Union Law. Some may argue that Eurospeak provides barely representative image of the legal language in respective member states since it leads to the processes of hybridization or even deculturization of national legal languages (Biel, 2016: 107-119, Ciostek, 2019: 27-42), which is not matter of dispute of the present article, though. In practice, EU law search engine turns out to be a very effective tool to spot major differences in the use of Latinisms between languages in question thanks to a multilingual view option. The sample tokens analyzed in the research shall be limited to ten Latin expressions: ipso facto, expressis verbis, pro tempore, nota bene, de cuius, affidavit, sine die, rebus sic stantibus, caveat and subpoena. Their selection shall be effected on the basis of overlapping records in at least two languages in terms of formal representation but deprived of semantic concordance between them. The quotations have been reported in extenso in order to show the full context in which certain terms have been solved. The latter shall be highlighted in bold to facilitate their visibility to the readers. The original text to be referred to as default is English, even if in some cases the Latin term appears in Italian or Polish translation only.

\section{Analysis}

\section{CASE 1: ipso facto}

\section{EN}

Farmers complying with the requirements laid down in Article 29(1) of Regulation (EC) No 834/2007 as regards organic farming shall be entitled ipso facto the payment referred to in this Chapter. ${ }^{1}$

1 h t t p : / / e u r - lex . e uropa.e u / L ex UriS e r v / L exUriS e r v. do?uri=OJ:C:2012:225:0174:0199:EN:PDF (accessed 14 Jan, 2021). 
IT

Gli agricoltori che soddisfano i requisiti di cui all'articolo 29, paragrafo 1, del regolamento (CE) n. 834/2007 per quanto riguarda l'agricoltura biologica hanno diritto ipso facto al pagamento di cui al presente capo. ${ }^{2}$

PL

Rolnicy spełniający wymogi określone w art. 29 ust. 1 Rozporządzenia (WE) nr 834/2007 w odniesieniu do rolnictwa ekologicznego są tym samym uprawnieni do płatności, o której mowa w niniejszym rozdziale. ${ }^{3}$

Ipso facto is a Latin phrase literally translated into English as "by the fact itself". Its meaning refers to a determined circumstance, which is a resultant effect of the action in question, instead of being caused by other event. This expression is mainly used in philosophy, law and science. Its presence in the aforementioned extract aims at emphasizing the fact that the farmers are entitled to certain benefits under the stated regulations. The term applied in the original English version has been transposed into the Italian translation (even though the occurrence of ipso facto in Italian is parallel to its native equivalent per il fatto stesso), whereas in the Polish translation a local term tym samym (=thereby) has been adopted since ipso facto is no lexically assimilated structure in Polish language. What is more, its hypothetical use in this particular context would bring too much pompousness to a typical normative phrase.

\section{CASE 2: expressis verbis}

\section{EN}

By letter dated 5 November 2003, registered as received on 7 November 2003, the Italian Permanent Representation to the European Union forwarded to the Commission a letter from the Italian authorities in which they stated expressly that, in view of the time that had elapsed since the dispatch of their last letter, they had reason to believe that they were in a situation where 'silence means assent' which made it possible for them to apply the rules as amended in the light of the Commission's comments. ${ }^{4}$

${ }^{2}$ http://eur-lex.europa.eu/LexUriServ/LexUriServ.do?uri=COM:2011:0625:FIN:IT:PDF (accessed 14 Jan, 2021).

3 h t t p : / / e u r - lex . europa.eu/LexUriServ/LexUriS erv. do?uri=OJ:C:2012:225:0174:0199:PL:PDF (accessed 14 Jan, 2021).

4 h t t p : / / e u r - lex.europa.e / L ex UriServ/LexUriS erv. do?uri=OJ:L:2006:085:0022:0035:EN:PDF (accessed 14 Jan, 2021). 
IT

Con lettera del 5 novembre 2003, protocollata il 7 novembre 2003, la Rappresentanza permanente dell'Italia presso l'Unione europea ha trasmesso alla Commissione una lettera delle autorità italiane nella quale queste ultime affermavano espressamente che, considerato il notevole lasso di tempo intercorso dall'invio della loro ultima comunicazione in merito alle misure di aiuto in oggetto, esse avevano motivo di ritenere che ci si potesse trovare in presenza di una forma di silenzio-assenso, che autorizzasse l'attuazione della normativa così come modificata a seguito dei rilievi della Commissione. ${ }^{5}$

PL

Pismem z dnia 5 listopada 2003 r., zarejestrowanym dnia 7 listopada 2003 r., Stałe Przedstawicielstwo Włoch przy Unii Europejskiej przekazało Komisji list od władz Włoch, w którym te ostatnie stwierdzają expressis verbis, że biorąc pod uwagę okres, jaki upłynął od chwili przekazania przez nie ostatniego listu, miały powody, aby uważać, że zaistniała sytuacja nosi znamiona sytuacji, w której milczenie wyraża zgodę, a tym samym pozwala im na stosowanie zasad zmienionych z uwzględnieniem uwag Komisji. ${ }^{6}$

The Latin term expressis verbis is translated into English as "expressly" or "explicitly". This approach is followed by Italian espressamente, unlike Polish language where the original structure is used with no need for its adaptation as the Polish equivalent "wyraźnie" has no such rigorous impact as the Latin formula does. Alternatively, Polish lawyers utilize explicite, which however sees lower occurrence in the EU law corpus.

\section{CASE 3: pro tempore}

\section{EN}

Annul the decision issued by - or, in any event, attributable to - the Commission to reject the claims set out in the applicant's request of 16 August 2011 sent to the Commission in the person of its legal representative pro tempore and to the appointing authority of the Commission. ${ }^{7}$

5 h t t p : / / e u r - lex.europa.eu/LexUriServ/Lex UriS e r v. do?uri=OJ:L:2006:085:0022:0035:IT:PDF (accessed 14 Jan, 2021).

6 h t t p : / / e ur-1 ex. e uropa. eu/L ex UriServ/LexUriServ. do?uri=OJ:L:2006:085:0022:0035:PL:PDF (accessed 14 Jan, 2021).

7 h t t p : / / e ur-1 ex . e u ropa. e u / L ex UriServ/Lex UriS e r v. do?uri=OJ:C:2012:065:0026:0027:EN:PDF (accessed 14 Jan, 2021). 


\section{IT}

Annullare la decisione, promanante ovvero comunque riconducibile alla Commissione, di ripulsa dei suoi petita di cui alla domanda datata 16 agosto 2011, inviata alla Commissione in persona del legale rappresentante pro tempore ed all'APN della Commissione. ${ }^{8}$

PL

Stwierdzenie nieważności decyzji przyjętej przez Komisję lub przypisywalnej Komisji o oddaleniu żądań skarżącego zawartych w jego wniosku z dnia 16 sierpnia 2011 r., przekazanym organowi powołującemu Komisji przez jego tymczasowego przedstawiciela prawnego. ${ }^{9}$

Pro tempore, often abbreviated to protem, is a Latin phrase translated into English as "for the time being". This expression is predominantly used to describe a person who acts as a locum tenens (temporarily taking place of another). In fact, its present meaning does not reflect much the original connotation of being one's substitute, but it assumes an autonomous form of "acting at present" or "representing here and now". This may provoke a little confusion since pro tempore in Italian language is understood more like provvisorio (=temporary) than attuale (=current) exactly as the Latin root implies. In Polish language this form has not been lexicalized at all and, as a matter of fact, results completely redundant. The decision of the European legislator to provide that Latinism as a loan word into Italian translation in such a context seems not to reflect much the position of the legal representative which is rather stable in the quoted procedure.

\section{CASE 4: nota bene}

\section{EN}

Note: The Commission will provide templates for the user manual for applicants and competent bodies and for the user manual for authorities awarding public contracts. $^{10}$

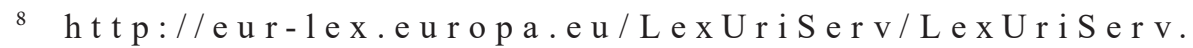
do?uri=OJ:C:2012:065:0026:0027:IT:PDF (accessed 14 Jan, 2021).

9 h t t p : / / e ur-1 ex . e u ropa. e u / L ex UriServ/Lex UriServ. do?uri=OJ:C:2012:065:0026:0027:PL:PDF (accessed 14 Jan, 2021).

$10 \mathrm{~h} \mathrm{t} \mathrm{t} \mathrm{p} \mathrm{:} \mathrm{/} \mathrm{/} \mathrm{e} \mathrm{u} \mathrm{r} \mathrm{-} \mathrm{lex} \mathrm{.} \mathrm{e} \mathrm{uropa} \mathrm{.} \mathrm{e} \mathrm{u} \mathrm{/} \mathrm{L} \mathrm{ex} \mathrm{UriS} \mathrm{e} \mathrm{r} \mathrm{v} \mathrm{/} \mathrm{L} \mathrm{ex} \mathrm{UriServ.}$ do?uri=COM:2008:0401:FIN:ENG:PDF (accessed 14 Jan, 2021). 
IT

Nota bene: la Commissione fornirà dei modelli per il manuale destinato ai richiedenti e agli organismi competenti e per il manuale destinato alle autorità aggiudicatrici di appalti pubblici. ${ }^{11}$

\section{PL}

Uwaga: Komisja dostarczy wzór podręcznika dla wnioskodawców i właściwych organów oraz wzór podręcznika dla władz udzielających zamówień publicznych. ${ }^{12}$

Nota bene, literally translated as "mark well", is used to add an aside or a warning to a provision, especially if this is a summons to appear in court or a caution given by the police. The Italian term nota bene retains perfectly its Latin meaning, whereas we observe a retreat from the original etymon in Polish language where, in order to maintain fidelity of translation, a native lexem uwaga or pouczenie shall be used. Surprisingly, Latin phrase nota bene exists in Polish (alternatively spelt notabene), but its sense has been deteriorated and it is closer now to English "by the way' (in fact, it is commonly confused in spoken language with another Latin expression nomen omen meaning "the name is a sign").

\section{CASE 5: de cuius}

\section{EN}

In the absence of valid justification, Article $43 \mathrm{EC}$ precludes inheritance tax legislation of a Member State which excludes from the exemption from that tax available for family undertakings those undertakings which employ in the three years preceding the date of death of the deceased at least five workers in another Member State, whereas it grants such an exemption where the workers are employed in a region of the first Member State. ${ }^{13}$

\section{IT}

In assenza di valida giustificazione, l'art. $43 \mathrm{CE}$ osta ad una disciplina tributaria di uno Stato membro in materia di imposte di successione che esclude dall'esenzione da tali imposte, prevista per le imprese familiari, le imprese che impiegano, nel corso dei tre anni precedenti la data del decesso de de cuius, almeno cinque

11 h t t p : / / e u r - 1 ex. e uropa.e u / L ex Uris e r v/Lex UriS e r v. do?uri=COM:2008:0401:FIN:IT:PDF (accessed 14 Jan, 2021).

$12 \mathrm{ht} \mathrm{tp://eur-1ex.europa.eu/LexUriServ/LexUriServ.}$ do?uri=COM:2008:0401:FIN:PL:PDF (accessed 14 Jan, 2021).

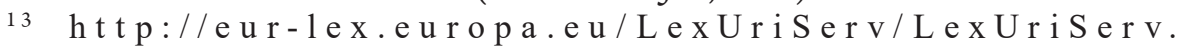
do?uri=OJ:C:2007:315:0011:0011:EN:PDF (accessed 14 Jan, 2021). 
lavoratori in un altro Stato membro, mentre concede una siffatta esenzione qualora i lavoratori siano impiegati in una regione del primo Stato membro. ${ }^{14}$

PL

W braku przekonywającego uzasadnienia, art. 43 WE sprzeciwia się uregulowaniu podatkowemu państwa członkowskiego w dziedzinie podatku od dziedziczenia, które wyklucza zwolnienie z tego podatku przewidziane dla spółek rodzinnych w przypadku spółek rodzinnych, które zatrudniały w okresie trzech lat poprzedzających zgon spadkodawcy co najmniej pięciu pracowników w innym państwie członkowskim, podczas gdy przyznaje takie zwolnienie wówczas, gdy pracownicy są zatrudnieni w jednym z regionów pierwszego państwa członkowskiego. ${ }^{15}$

Latin expression de cuius, which falls within the scope of inheritance law, is referred to as a deceased person who left property to heirs. The term derives from a more extended phrase de cuius hereditate agitur (=of the person of whom one is speaking) and has been adopted in Italian to retain the meaning of the figure, who is known in English as "testator" and respectively in Polish as "spadkodawca". The absence of a native Italian word and the need for using a Latin lexicalized structure (which is originally not a noun but a relative pronoun, though) may be surprising, but the same problem is also observed in French where de cujus is preferred.

\section{CASE 6: affidavit}

\section{EN}

Because the primary responsibility is on the contract holder to ensure that its owners are eligible persons, the contract holder is to execute an affidavit that it is in compliance. ${ }^{16}$

\section{IT}

Poiché spetta principalmente al titolare del contratto garantire che i propri proprietari siano persone ammissibili, è egli stesso a dover eseguire un affidavit conforme. ${ }^{17}$

14 h t t p : / / e u r - lex . e u ropa . e u / L ex UriServ/Lex UriServ. do?uri=OJ:C:2007:315:0011:0012:IT:PDF (accessed 14 Jan, 2021).

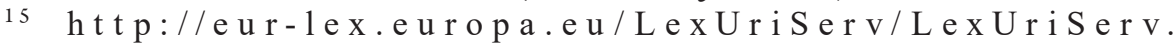
do?uri=OJ:C:2007:315:0011:0012:PL:PDF (accessed 14 Jan, 2021).

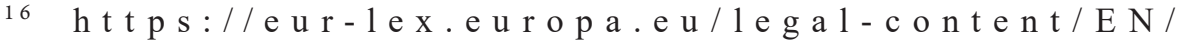
TXT/?uri=CELEX\%3A32012D0373\&qid=1610564347686 (accessed 14 Jan, 2021).

17 h t t p s : / / e u r - lex.e uropa.e u / 1 e g a 1 - c o n t e n t / I T/ TXT/?uri=CELEX\%3A32012D0373\&qid=1610564347686 (accessed 14 Jan, 2021). 
PL

Ponieważ na zleceniobiorcy spoczywa głównie odpowiedzialność za to, aby jego właściciele byli osobami uprawnionymi, ma on złożyć pisemne oświadczenie, że tak faktycznie jest. ${ }^{18}$

The Latin term affidavit indicates a written statement, usually made under oath, given by witnesses to prove authenticity of the act and may serve as evidence in court proceedings. Apparently, it originated earlier in the Englishspeaking area and was subsequently transposed into Italian in the banking area where its meaning is related to declarations affirming that a debtor is solvent and trustworthy. Polish written sources do not provide reliable evidence that affidavit is applicable to any extent in Polish legal language (merely few examples of records spotted via SAOS - System Analizy Orzeczeń Sądowych (Automatic Court Judgment Similarity Analysis) imply that its use was either foreignoriented or erroneous).

\section{CASE 7: sine die}

\section{EN}

A more active, effective EU 'foreign policy' has taken shape with the gradual enlargement of its geographical borders to the east and south. It has worked well thus far but the process has yet to be completed, with the negotiations underway with the Balkans and Turkey; these negotiations cannot be drawn out indefinitely but must be undertaken openly, without preconceptions or fears, by both sides. ${ }^{19}$

\section{IT}

Una «politica estera» più attiva ed efficace dell'Unione, che finora ha funzionato, si è concretizzata attraverso il graduale allargamento dei suoi confini geografici, verso Est e verso Sud. Questo processo deve essere ancora completato con il negoziato in corso con gli Stati balcanici e con la Turchia, che non può essere procrastinato sine die; va invece affrontato a viso aperto, senza preconcetti o timori da entrambe le parti. ${ }^{20}$

18 h t t p s : / / e u r - lex.europa.e u / l e g a l-content/PL/ TXT/?uri=CELEX\%3A32012D0373\&qid=1610564347686 (accessed 14 Jan, 2021).

$19 \mathrm{ht} \mathrm{tps://eur-1ex.europa.eu/LexUriServ/LexUriServ.}$ do?uri=OJ:C:2012:024:0056:0062:EN:PDF (accessed 14 Jan, 2021).

20 h t t p s : / / e ur-1 ex. europa.e u / L ex UriServ/LexUris e r v . do?uri=OJ:C:2012:024:0056:0062:IT:PDF (accessed 14 Jan, 2021). 
PL

Funkcjonująca dotychczas aktywniejsza i skuteczniejsza polityka zagraniczna UE znalazła swój konkretny wyraz w stopniowym poszerzaniu geograficznego obszaru zainteresowania na wschód i południe. Proces ten należy obecnie uzupełnić o bieżące negocjacje z krajami bałkańskimi i Turcją, których nie można odkładać bezterminowo, lecz zamiast tego należy im otwarcie stawić czoła bez kierowania się przez którąkolwiek ze stron uprzedzeniami lub obawami. ${ }^{21}$

Sine die in Italian legal language refers to proceedings that have been postponed without scheduling a new date. This connotation is most likely retained by English adverb "indefinitely" in the first instance, alternatively it appears as part of a hybrid expression "adjournment sine die”, but never as an autonomous or lexicalized phrase. In turn, Polish legal language prefers its native equivalent "bezterminowo" (or a related adverbial locution "bez terminu”), however another Latin phrase ad Calendas Graecas (=at no time) is widespread in both legal and standard Polish register.

\section{CASE 8: rebus sic stantibus}

\section{EN}

As matters stand, the European Research Area must be given the best possible chances of organising an extremely competitive and dynamic environment, where human resources have better long-term prospects throughout their career paths. ${ }^{22}$

\section{IT}

Rebus sic stantibus, lo spazio europeo della ricerca deve essere messo nelle migliori condizioni per organizzare un ambiente fortemente competitivo e dinamico dove le risorse umane possano trovare prospettive di carriera migliori e sostenibili durante l'intero percorso lavorativo. ${ }^{23}$

PL

W tej sytuacji należy zapewnić jak najlepsze warunki do tego, by europejska przestrzeń badawcza mogła stworzyć bardzo konkurencyjne i dynamiczne środowisko, w którym naukowcy mogliby znaleźć lepsze i trwałe warunki dla kariery przez cały okres życia zawodowego. ${ }^{24}$

21 h t t p s : / / e ur- lex . e uropa.e u / LexUris erv/Lex UriServ. do?uri=OJ:C:2012:024:0056:0062:PL:PDF (accessed 14 Jan, 2021).

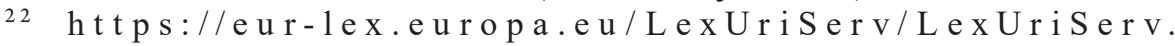
do?uri=OJ:C:2009:175:0081:0083:EN:PDF (accessed 14 Jan, 2021).

23 ht t p s://eur-1 ex.europa.eu/LexUriServ/LexUriServ. do?uri=OJ:C:2009:175:0081:0083:IT:PDF (accessed 14 Jan, 2021).

$24 \mathrm{ht} \mathrm{tps}$ : / / u r-1ex.europa.eu/LexUriServ/Lex UriServ. do?uri=OJ:C:2009:175:0081:0083:PL:PDF (accessed 14 Jan, 2021). 
The phrase rebus sic stantibus (Latin for "things are standing as they stand") in Italian language (both legal and non-legal) is related to a situation that has already been examined and discussed. In more specialized contexts, this refers to a principle of private law, according to which parties can withdraw from the contract in the event of unforeseen circumstances that prevent its fulfillment (e.g. caused by force majeure). Such clause exists in all legal systems which descend from Roman law (including Polish civil code, see art. 3571) and in some of the common law states. However, the expression rebus sic stantibus itself does not occur in English and Polish outside that meaning and it is retained by native structures ("as matters stand" and "w tej sytuacji / skoro sprawy przybrały taki obrót" respectively) in the above-mentioned EU legislation.

\section{CASE 9: caveat}

\section{EN}

Taking due account of the caveat at 3.1, Europe should move as quickly as possible towards a more market-based approach to spectrum management, with more empowerment of market players and the introduction of more widespread spectrum trading, and with less national bureaucratic prescription on bandwidth allocation. ${ }^{25}$

\section{IT}

Tenendo nel dovuto conto la premessa di cui al punto precedente, l'Unione europea dovrebbe passare il più rapidamente possibile ad un approccio alla gestione dello spettro radio che sia maggiormente basato sul mercato, dando più poteri agli attori presenti sul mercato, introducendo un più ampio sistema per lo scambio delle licenze, e riducendo invece le prescrizioni burocratiche nazionali relative all'assegnazione delle bande. ${ }^{26}$

\section{PL}

Należycie uwzględniając zastrzeżenie zgłoszone w powyższym punkcie 3.1, Europa powinna jak najszybciej zmierzać w kierunku przyjęcia podejścia rynkowego do zarządzania spektrum radiowym, przekazując więcej uprawnień podmiotom na rynku, wprowadzając zakrojony na szerszą skalę handel częstotliwościami oraz ograniczając krajowe przepisy biurokratyczne odnośnie do przyznawania szerokości pasma. ${ }^{27}$

25 ht tps: / / eur-1ex.europa.eu/LexUriServ/LexUriServ. do?uri=OJ:C:2007:097:0027:0032:EN:PDF (accessed 14 Jan, 2021).

26 ht t p s : / / e ur-1 ex.europa.eu/LexUriServ/Lex UriServ. do?uri=OJ:C:2007:097:0027:0032:IT:PDF (accessed 14 Jan, 2021).

27 h t t p s : / / e ur-1 ex . e uropa.eu/LexUriserv/LexUriServ. do?uri=OJ:C:2007:097:0027:0032:PL:PDF (accessed 14 Jan, 2021). 
Caveat derives from the Latin verb cavere of the 2 nd conjugation type meaning "beware" and represents the 3 rd person singular of imperative (=may he beware of). Grammatically speaking, it was nominalized long before due to several principles that English common law adopted from ancient Rome's legal system such as caveat emptor ("buyer beware") applicable in commercial law or a hybrid caveat loan (=bridge or swing loan) used to name a sum of money borrowed for a short period of time to cover expenses until new funds become available. That is why caveat began to function in English legal language outside the original context as a synonym of "warning". Neither Polish nor Italian national corpora recognize it as lexicalized term (as it was highlighted above in the quoted EU law provisions).

\section{CASE 10: subpoena}

\section{EN}

Indeed, the Explanatory Memorandum to the 1980 OECD Privacy Guidelines makes clear that an organization's access obligation is not absolute. It does not require the exceedingly thorough search mandated, for example, by a subpoena, nor does it require access to all the different forms in which the information may be maintained by the organization. ${ }^{28}$

\section{IT}

Effettivamente il Memorandum sulle Linee guida dell'OCSE del 1980 sulla tutela della sfera privata afferma chiaramente che per un'organizzazione l'obbligo di fornire l'accesso non è assoluto. Esso non impone una ricerca scrupolosa quale quella necessaria, ad esempio, per un mandato di comparizione, né l'accesso a tutte le varie forme in cui l'organizzazione può detenere dati. ${ }^{29}$

PL

Potwierdzają to uzasadnienia do Wytycznych OECD w sprawie ochrony prywatności z 1980 r., które jasno stwierdzają, że obowiązek udzielenia dostępu przez organizację nie jest nieograniczony. Nie wymaga on nadmiernie szczegółowego przeszukania nakazanego, na przykład, w wezwaniu sądowym, ani nie wymaga dostępu do informacji we wszystkich poszczególnych, w jakich może ona być przechowywana przez organizacje.. ${ }^{30}$

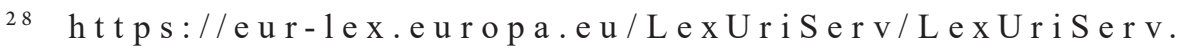
do?uri=OJ:L:2000:215:0007:0047:EN:PDF (accessed 14 Jan, 2021).

29 h t t p s : / / e ur-1 ex . e uropa.e u / LexUris erv/Lex UriS e r v. do?uri=OJ:L:2000:215:0007:0047:IT:PDF (accessed 14 Jan, 2021).

30 h t t p s : / / e ur-1 ex . europa.eu/LexUris erv/LexUriServ. do?uri=OJ:L:2000:215:0007:0047:PL:PDF (accessed 14 Jan, 2021). 
Subpoena, as an abbreviated form of subpoena ad testificandum (SAT) originated from Medieval Latin (literally: "under penalty to testify"), was incorporated into English in the 17th century. The term provides the meaning of "a summons obliging witnesses to appear in court and give testimony". However, nowadays its understanding is gradually declining, that is why subpoena is being replaced more and more with its plain English equivalents (such as "summons" or "citation"). It remains obscure for both Italian and Polish legal language, too.

\section{Concluding remarks}

In summary, the aim of the analysis was to outline some practical problems related to both formal or semantic incompatibility of several Latin expressions present in English language, but absent in Italian and Polish or vice versa, as well as to raise awareness of the phenomenon of apparent or false connotations of Latinisms between mentioned languages. The studied examples seem to meet the initial assumption of partial or non-equivalence of Latin terms among selected representatives of Germanic, Romance and Slavonic languages. The gathered sample, even if characterized by low distribution value on one hand and highly specific purposes on the other, falls therefore within the framework of research into Latin legal terms overall. It confirms that there is an urgent need to create a contrastive up-to-date platform denoting legal Latinisms for legal translators, which can be applicable off-hand without further insight into the meaning of complex structures of each European language. Otherwise, the formal correspondence intended by Eugene Nida as one that "focuses attention on the message itself, in both form and content", unlike dynamic equivalence which is based on "the principle of equivalent effect" (Nida, 1964: 159), may easily lead to miscomprehension or discrepancy of translation. Following that rule, this is the dynamic equivalence that tend to be applied consensually so as to retain the meaning of the original (as seen in the examples of section 4). Since there is still no unified multilingual Latin dictionary of terms highlighting their prescriptive usage in the contemporary European languages, this is translator's prerogative (and obligation at the same time) to decode properly the significance of a Latinism before transposing it or not into the target language. A comparative study of accessible instruments (including open source corpora) is of great relevance for such operations performed for both academic and professional purposes. 


\section{Bibliography}

\section{Quoted references}

Biel, Ł. (2016): Tłumaczenie prawa unijnego a centralne pojęcia przekładoznawstwa. Między Oryginałem a Przekładem, 3 (33), pp. 107-119.

Ciostek, A. (2019): Terminologia Unii Europejskiej i brukselizmy: ewolucja. Socjolingwistyka, 33, pp. 27-42.

Koźbial, D. (2020): The Language of EU and Polish Judges: Investigating Textual Fit Through Corpus Methods. Berlin: Peter Lang Publishing.

Kurzon, D. (1987): Latin for Lawyers: Degrees of Textual Integration. Applied Linguistics, 8, pp. 233-240.

Mortara Garavelli, B. (2001): Le parole e la giustizia. Divagazioni grammaticali e retoriche su testi giuridici italiani. Torino: Einaudi.

Mortara Garavelli, B. (2002): Persistenza del latino nell'uso giuridico odierno. In: Maraschio, N. (ed.), L’Accademia della Crusca per Giovanni Nencioni, pp. 423-433. Firenze: Le Lettere.

Nida, E.A. (1964): Towards a Science of Translating. Leiden: E. J. Brill.

Oates, L., Enquist, A. (2009): Just Writing: Grammar, Punctuation, and Style for the Legal Writer (Rev. ed.). New York: Aspen Publishers.

Ramsfield, J. (2005): Culture to Culture: A Guide to U.S. Legal Writing. Durham, NC: Carolina Academic Press.

Wróblewski, B. (1948): Język prawny i prawniczy. Kraków: Polska Akademia Umiejętności.

Zieliński, M. (1999): Języki prawne i prawnicze. In: Pisarek, W. (ed.). Polszczyzna 2000: orędzie o stanie języka na przełomie tysiącleci, pp. 50-74. Kraków: Ośrodek Badań Prasoznawczych, Uniwersytet Jagielloński.

\section{Further reading}

Bertozzi, P. (2009): Dizionario dei brocardi e dei latinismi giuridici. Milano: Wolters Kluwer Italia.

Del Giudice, F. (2015): Il latino in tribunale. Brocardi e termini latini in uso nella pratica forense. Napoli: Simone.

Giampieri, P. (2015): Legal English. Tradurre da/verso l'inglese giuridico. Milano: Giuffrè Editore.

Giomini, R., Cosi., P. (2008): Bonus malus. Il latino degli italiani. Una raccolta di oltre 1.000 espressioni latine in uso nella lingua italiana. Roma: Società Editrice Dante Alighieri.

Hermann, M. (2014): O łacinie tylko dobrze. De lingua latina nil nisi bene. Kraków: Universitas.

Leonardi, V. (2000): Equivalence in Translation: beetween Myth and Reality. Translation Journal, https://translationjournal.net/journal/14equiv.htm (accessed 14 Jan, 2021).

Tessuto, J. (1998): Legal English in Theory and Practice: New Features, Specialist Terminology \& Translation Texts. Torino: G. Giappichelli Editore. 
Wołodkiewicz, W., Krzyżówek, J. (2001): Łacińskie paremie w europejskiej kulturze prawnej i orzecznictwie sądów polskich. Warszawa: Liber.

Woźniak, J. (2018): Latinisms in Legal Texts - A Contrastive Approach Polish-German. Comparative Legilinguistics, 31, pp. 69-88.

\section{Web references}

http://eur-lex.europa.eu/LexUriServ/LexUriServ.do?uri=COM:2008:0401:FIN:ENG:PDF (accessed 14Jan, 2021).

http://eur-lex.europa.eu/LexUriServ/LexUriServ.do?uri=COM:2008:0401:FIN:IT:PDF (accessed 14Jan, 2021).

http://eur-lex.europa.eu/LexUriServ/LexUriServ.do?uri=COM:2008:0401:FIN:PL:PDF (accessed 14 Jan, 2021).

http://eur-lex.europa.eu/LexUriServ/LexUriServ.do?uri=COM:2011:0625:FIN:IT:PDF (accessed 14Jan, 2021).

http://eur-lex.europa.eu/LexUriServ/LexUriServ.do?uri=OJ:C:2007:315:0011:0011:EN:PDF (accessed 14Jan, 2021).

http://eur-lex.europa.eu/LexUriServ/LexUriServ.do?uri=OJ:C:2007:315:0011:0012:IT:PDF (accessed 14Jan, 2021).

http://eur-lex.europa.eu/LexUriServ/LexUriServ.do?uri=OJ:C:2007:315:0011:0012:PL:PDF (accessed 14Jan, 2021).

http://eur-lex.europa.eu/LexUriServ/LexUriServ.do?uri=OJ:C:2012:065:0026:0027:EN:PDF (accessed 14Jan, 2021).

http://eur-lex.europa.eu/LexUriServ/LexUriServ.do?uri=OJ:C:2012:065:0026:0027:IT:PDF (accessed 14Jan, 2021).

http://eur-lex.europa.eu/LexUriServ/LexUriServ.do?uri=OJ:C:2012:065:0026:0027:PL:PDF (accessed 14Jan, 2021).

http://eur-lex.europa.eu/LexUriServ/LexUriServ.do?uri=OJ:C:2012:225:0174:0199:EN:PDF (accessed 14Jan, 2021).

http://eur-lex.europa.eu/LexUriServ/LexUriServ.do?uri=OJ:C:2012:225:0174:0199:PL:PDF (accessed 14Jan, 2021).

http://eur-lex.europa.eu/LexUriServ/LexUriServ.do?uri=OJ:L:2006:085:0022:0035:EN:PDF (accessed 14Jan, 2021).

http://eur-lex.europa.eu/LexUriServ/LexUriServ.do?uri=OJ:L:2006:085:0022:0035:IT:PDF (accessed 14Jan, 2021).

http://eur-lex.europa.eu/LexUriServ/LexUriServ.do?uri=OJ:L:2006:085:0022:0035:PL:PDF (accessed 14Jan, 2021).

h t t p s : / / e u r - l e x . e u r o p a . e u / l e g a l-content / E N / TXT/?uri=CELEX\%3A32012D0373\&qid=1610564347686 (accessed 14Jan, 2021).

h t t p s : / / e u r - l e x . e u r o p a . e u / l e g a l - c o n t e n t / I T / TXT/?uri=CELEX\%3A32012D0373\&qid=1610564347686 (accessed 14Jan, 2021).

h t t p s : / / e u r - l ex . e u r o p a . e u / l e g a l-content / P L / TXT/?uri=CELEX\%3A32012D0373\&qid=1610564347686 (accessed 14 Jan, 2021). https://eur-lex.europa.eu/LexUriServ/LexUriServ.do?uri=OJ:C:2007:097:0027:0032:EN:PDF (accessed 14Jan, 2021). 
https://eur-lex.europa.eu/LexUriServ/LexUriServ.do?uri=OJ:C:2007:097:0027:0032:IT:PDF (accessed 14Jan, 2021).

https://eur-lex.europa.eu/LexUriServ/LexUriServ.do?uri=OJ:C:2007:097:0027:0032:PL:PDF (accessed 14Jan, 2021).

https://eur-lex.europa.eu/LexUriServ/LexUriServ.do?uri=OJ:C:2009:175:0081:0083:EN:PDF (accessed 14Jan, 2021).

https://eur-lex.europa.eu/LexUriServ/LexUriServ.do?uri=OJ:C:2009:175:0081:0083:IT:PDF (accessed 14Jan, 2021).

https://eur-lex.europa.eu/LexUriServ/LexUriServ.do?uri=OJ:C:2009:175:0081:0083:PL:PDF (accessed 14Jan, 2021).

https://eur-lex.europa.eu/LexUriServ/LexUriServ.do?uri=OJ:C:2012:024:0056:0062:EN:PDF (accessed 14Jan, 2021).

https://eur-lex.europa.eu/LexUriServ/LexUriServ.do?uri=OJ:C:2012:024:0056:0062:IT:PDF (accessed 14Jan, 2021).

https://eur-lex.europa.eu/LexUriServ/LexUriServ.do?uri=OJ:C:2012:024:0056:0062:PL:PDF (accessed 14Jan, 2021).

https://eur-lex.europa.eu/LexUriServ/LexUriServ.do?uri=OJ:L:2000:215:0007:0047:EN:PDF (accessed 14Jan, 2021).

https://eur-lex.europa.eu/LexUriServ/LexUriServ.do?uri=OJ:L:2000:215:0007:0047:IT:PDF (accessed 14Jan, 2021).

https://eur-lex.europa.eu/LexUriServ/LexUriServ.do?uri=OJ:L:2000:215:0007:0047:PL:PDF (accessed 14Jan, 2021). 